\title{
Maximal muscular power: lessons from sprint cycling
}

Jamie Douglas ${ }^{1,2^{*}}$, Angus Ross ${ }^{1}$ and James C. Martin ${ }^{3}$

\begin{abstract}
Maximal muscular power production is of fundamental importance to human functional capacity and feats of performance. Here, we present a synthesis of literature pertaining to physiological systems that limit maximal muscular power during cyclic actions characteristic of locomotor behaviours, and how they adapt to training. Maximal, cyclic muscular power is known to be the main determinant of sprint cycling performance, and therefore we present this synthesis in the context of sprint cycling. Cyclical power is interactively constrained by forcevelocity properties (i.e. maximum force and maximum shortening velocity), activation-relaxation kinetics and muscle coordination across the continuum of cycle frequencies, with the relative influence of each factor being frequency dependent. Muscle cross-sectional area and fibre composition appear to be the most prominent properties influencing maximal muscular power and the power-frequency relationship. Due to the role of muscle fibre composition in determining maximum shortening velocity and activation-relaxation kinetics, it remains unclear how improvable these properties are with training. Increases in maximal muscular power may therefore arise primarily from improvements in maximum force production and neuromuscular coordination via appropriate training. Because maximal efforts may need to be sustained for 15-60 s within sprint cycling competition, the ability to attenuate fatigue-related power loss is also critical to performance. Within this context, the fatigued state is characterised by impairments in force-velocity properties and activation-relaxation kinetics. A suppression and leftward shift of the power-frequency relationship is subsequently observed. It is not clear if rates of power loss can be improved with training, even in the presence adaptations associated with fatigue-resistance. Increasing maximum power may be most efficacious for improving sustained power during brief maximal efforts, although the inclusion of sprint interval training likely remains beneficial. Therefore, evidence from sprint cycling indicates that brief maximal muscular power production under cyclical conditions can be readily improved via appropriate training, with direct implications for sprint cycling as well as other athletic and health-related pursuits.
\end{abstract}

Keywords: Muscular power, Fatigue, Sprint cycling, Performance

\section{Key Points}

- Maximal muscle power production under cyclical conditions is interactively constrained by forcevelocity properties, activation-relaxation kinetics and muscle coordination across the continuum of possible movement frequencies.

\footnotetext{
* Correspondence: jamie.douglas@hpsnz.org.nz

${ }^{1}$ High Performance Sport New Zealand (HPSNZ), Avantidrome, 15 Hanlin Road, Cambridge 3283, New Zealand

${ }^{2}$ Cycling New Zealand, Cambridge, New Zealand

Full list of author information is available at the end of the article
}

- Fatigue alters the power-frequency relationship, with a higher degree of power loss at higher movement frequencies.

- Maximal muscular power production can be readily increased with appropriate strength and power training; it remains less clear if rates of power loss during brief maximal sustained efforts can be improved with training.

\section{Introduction}

Feats of strength, speed and power have captivated humans for millennia and every 4 years, Olympic events 
which exhibit the (contemporary) limits of human performance are followed with intent by millions internationally. Such feats of human potential are fundamentally determined by muscular mechanical function, and especially, maximal muscular power. Indeed, outside the world of sport, maximal muscular power is often of life-or-death importance in predatorprey interaction and is important in health and disease. Track sprint cycling is an Olympic sport in which some of the most powerful athletes in the world generate remarkable speeds on a bicycle, with Olympic gold and fourth place often separated by only hundredths of a second. Previous investigators have reported that sprint cycling performance is largely determined by maximal muscular power production [1] and therefore serves as a useful model to investigate and advance the limits maximal muscular power by scientists and practitioners alike. Here, we present a synthesis of literature pertaining to physiological systems that limit maximal muscular power during cyclic actions characteristic of locomotor behaviours, and how they adapt to training, framed within the context of sprint cycling.

There are several sprint cycling events and currently three are contested at the Olympics (i.e. Match Sprint, Keirin and Team Sprint). Each event has its own nuanced technical, tactical and physiological demands, but there is substantial cross-over and multi-event Olympic champions are not uncommon. Cycling performance (e.g. velocity or time) is determined exclusively by the balance between propulsive power and resistance [1-8]. Power demand may be divided primarily into the power required to overcome aerodynamic drag, rolling resistance and drive train friction, and to bring about a change in potential or kinetic energy [1, 2, 6, 7]. The relative importance of these terms is dependent upon the instantaneous conditions and can change within a sprint cycling event [1]. During brief maximal accelerations from low speed, the change in kinetic energy will consume most of the power (Fig. 1) [9], and is related to mass and acceleration [10]. Because maximal accelerations are often initiated from a slow rolling or standing start in sprint cycling, power demand is directly proportional to the combined mass of the bicycle and rider [1]. At steady state speeds above $\sim 40 \mathrm{~km} / \mathrm{h}$ on flat terrain more than $90 \%$ of power is required to overcome air resistance, which is related to air density, frontal area, shape and velocity $[10,11]$. Air (or aerodynamic) resistance (force) is proportional to the square of air speed, and power is related to the product of air speed squared and ground speed. With increasing speed, an exponentially larger increase in power is required to achieve a further increase in speed $[1,5,6,10]$. Therefore, rider aerodynamic drag which is most commonly quantified as the drag area $\left(\mathrm{C}_{\mathrm{D}} \mathrm{A}\right.$; a term combining the rider drag

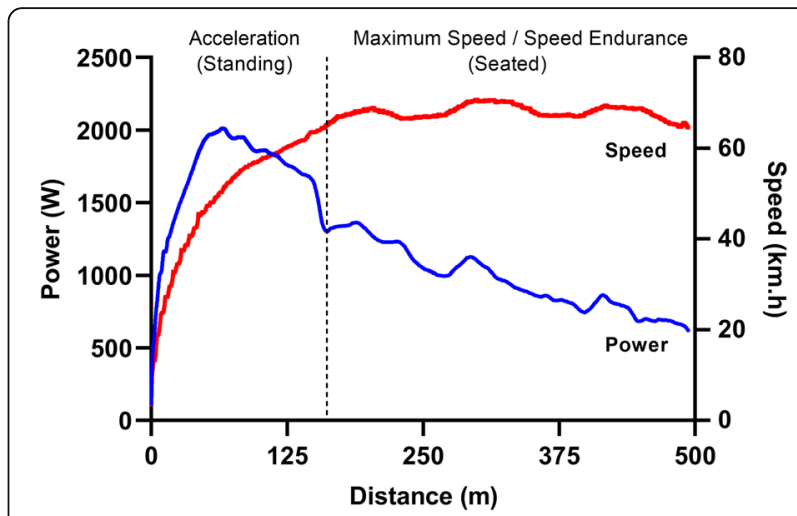

Fig. 1 An example power profile and resulting speed from a highly trained male sprint cyclist during a maximal $500 \mathrm{~m}$ effort performed from a standing start (with an effort duration of $31.91 \mathrm{~s}$ ). The dotted vertical line represents the transition from standing to seated cycling and is an approximate demarcation between acceleration and maximum speed/speed endurance phases

coefficient and frontal area) will account for most of the power demand at high speed [1], and reinforces the advantages of drafting where possible during sprint cycling competition [12, 13].

Power supply is determined by neuromuscular and metabolic capabilities [6]. Accordingly, due to the very high levels of muscular power required to generate high movement velocities, sprint cyclists tend to be more mesomorphic, stronger and more maximally powerful than other (i.e. endurance) cyclists [14-17]. The constraints inherent to human muscle contractile function and bioenergetics mean that power supply is limited in both rate and capacity from aerobic and anaerobic energy sources [18, 19], and so a negative exponential power-duration relationship is observed during maximal efforts [20]. In addition, both maximal and sustained (i.e. for a given event duration) power production are pedalling-rate dependent $[4,6]$. As sprint cycling is performed on fixed-gear bicycles, the pedalling rate is nonconstant and dependent upon the interaction of gear ratio and speed. The optimal power supply strategy (i.e. pedalling rate selection via gearing, and pacing) will therefore be dependent upon individual athlete characteristics, event distance, technical and tactical requirements [18, 21, 22]. Increasing maximal power for a given bicycle-rider mass will be most beneficial to improving the maximal rate of acceleration from a standing start, whilst increasing maximal and sustained power for a given $C_{D} A$ will be most beneficial to increasing maximum speed and speed endurance. Assuming technical/ tactical competency and access to modern (i.e. aerodynamic) equipment [11], the sprint cyclist that exhibits the highest levels of maximum and sustained power relative to their body mass and $\mathrm{C}_{\mathrm{D}} \mathrm{A}$ will be the fastest [23], and generally the most successful [24]. 


\section{Maximal Cycling Power}

\section{Mechanical Basis of Maximal Cycling Power}

Cycling is a motor task which involves the co-ordination the lower body prime movers operating in cyclic phases of shortening and lengthening to move the pedal (i.e. via the foot-pedal interface) in a circular trajectory at a given movement speed or pedalling rate, whilst applying the requisite force to the pedal necessary to achieve a given power output $[25,26]$. Mechanical power is the product of force and velocity, or torque and angular velocity in the context of cycling [27-29]. Within fixed gear cycling, pedal forces directed normal to the crank (i.e. torque) will facilitate pedalling rate and power production; however, the increasing pedalling rate will then constrain maximal force and power via force-velocity and activation-relaxation effects (the 'Physiological Basis of Maximal Cycling Power' section). Power may be determined in several different ways, but it is generally reported as the average power produced by both legs over a half pedal cycle from top dead-centre to bottom deadcentre $[30,31]$, or a complete pedal cycle $[1,6,32]$. In research settings, specialised ergometers have been developed to measure torque, pedalling rate and power production [30-35], and in applied settings, power produced by sprint cyclists is typically measured via commercially available cranks instrumented with strain gauges (e.g. the SRM [Schoberer Rad Messtechnik Jülich, Germany] power metre) [1, 36, 37]. Maximum power values as high as $2400-2500 \mathrm{~W}$ and $25-26 \mathrm{~W}^{-\mathrm{kg}^{-1}}$ have been reported in elite male track sprint and BMX cyclists $[1,25,38]$, and values of $20-23 \mathrm{~W} . \mathrm{kg}^{-1}$ (e.g. 1400$1600 \mathrm{~W}$ at a body mass of $70 \mathrm{~kg}$ ) reported in elite female track sprint cyclists [39].

Males produce $\sim 25 \%$ more maximal power than females due to a larger muscle mass [39-41], and possibly a higher relative area of muscle mass comprised of fast twitch fibres $[42,43]$, with muscle mass and fibre composition being strongly linked to maximal power production (the 'Physiological Basis of Maximal Cycling Power' section) [32, 44, 45]. Approximately $~ 80-85 \%$ of the power produced over a pedal cycle is generated during leg extension (i.e. the downstroke), whilst $\sim 15-20 \%$ is produced during leg flexion (i.e. the upstroke) [26, 46]. This power is a product of joint-specific actions of the ankle, knee and hip, and by upper body actions which transfer power across the hip [46, 47]. Hip extension contributes the most to total power output during maximal cycling, followed by knee extension, knee flexion, and finally ankle plantarflexion [46, 47]. During standing cycling $\sim 8-12 \%$ more maximum power may be produced versus seated cycling $[48,49]$ via a transfer of power across the hip from the upper body [6, 50]. Whilst it has been proposed that the lower body prime movers are not fully active (e.g. as ascertained from electromyographic [EMG] activity) during maximal cycling $[51,52]$, simulation data indicates that agonist musculature is operating at or near its maximal capacity [53]. Nonetheless, it should be acknowledged that the use of EMG data to assess muscle activation remains contentious [54], and a high degree of variability has been reported during maximal cycling [55]. Additionally, simulations of muscular behaviour rely on several assumptions which may not hold for all individuals or circumstances [53].

\section{Physiological Basis of Maximal Cycling Power}

The maximal 'fatigue-free' power that can be produced during a cycling bout is determined by an interaction of intrinsic muscle properties, neural activation and constraints (e.g. movement velocity and time available to produce force) imposed by the task [56, 57]. Intrinsic properties governing muscle force production during cyclic contractions include the force-length and forcevelocity (i.e. maximum force and maximum shortening velocity) relationships, activation-relaxation kinetics (i.e. the time required to activate and relax muscle following neural excitation) and history-dependent effects (i.e. force enhancement after active lengthening, and force depression after shortening) [56-60]. Given the direct relationships between crank length and muscle excursion amplitude, pedal velocity and muscle shortening velocity, and pedalling rate and excitation-relaxation kinetics, these variables interactively constrain power production during sprint cycling $[57,61]$. Because the hip and knee extensors appear to actively lengthen immediately preceding shortening during maximal cycling [62, 63], there may be a history-dependent attenuation of the force-length effects on force production, especially at long muscle lengths [64]. This proposition is supported by the finding that pedal and joint-specific power production does not meaningfully change across a broad range (e.g. 145 to $195 \mathrm{~mm}$ ) of crank lengths $[65,66]$. Force-velocity and activation-relaxation requirements placed on muscle are linearly coupled for a given crank length during cycling [58, 66, 67], and therefore maximal muscle power production during sprint cycling (i.e. for a given individual) is determined primarily by pedalling rate.

The relationships between torque, power and pedalling rate during cycling generally conform to the forcevelocity and power-velocity relationships observed within isolated muscle [32, 34, 68], acknowledging that there is a linear rather than hyperbolic relationship between force and velocity during cycling [32, 38, 69-71]. Accordingly, there is a negative linear relationship between torque and pedalling rate, and a parabolic relationship between power and pedalling rate, with maximum power occurring at approximately half of the 
respective maximum torque and maximum pedalling rate values (Fig. 2) [23, 25, 32, 69]. The apex of the power-pedalling rate relationship typically occurs at an 'optimal cadence' (i.e. 'optimal frequency') of 120-130 rpm [6]. Higher optimal cadence values tend to be observed in conjunction with higher maximum power values [25, 72], which is unsurprising as both parameters are strongly linked to fast twitch (i.e. skeletal muscle fibres expressing a predominance of myosin heavy chain [MyHC] IIa and IIx isoforms) muscle fibre content [30, 45, 68]. An evenly mixed distribution of fast and slow twitch fibres across agonist musculature has been proposed to produce an optimal cadence of around $120 \mathrm{rpm}$ in healthy non-power trained adults [30, 31, 45, 72]. Power trained athletes and individuals genetically endowed with a high proportion of fast twitch fibres may exhibit optimal cadences of $130 \mathrm{rpm}$ and above [72-74].

Maximum muscle force and shortening velocity set the limits of the intrinsic muscle-force velocity relationship and power production at any given shortening velocity is determined by the interaction of these two parameters [28]. Maximum force will therefore directly influence the magnitude and rate of torque production at any given pedalling rate during cycling $[28,75]$. The maximum force generated by a muscle fibre of any given $\mathrm{MyHC}$ isoform is directly proportional to its crosssectional area [28, 76, 77]. Fast twitch fibre composition influences intrinsic force-velocity properties and muscle

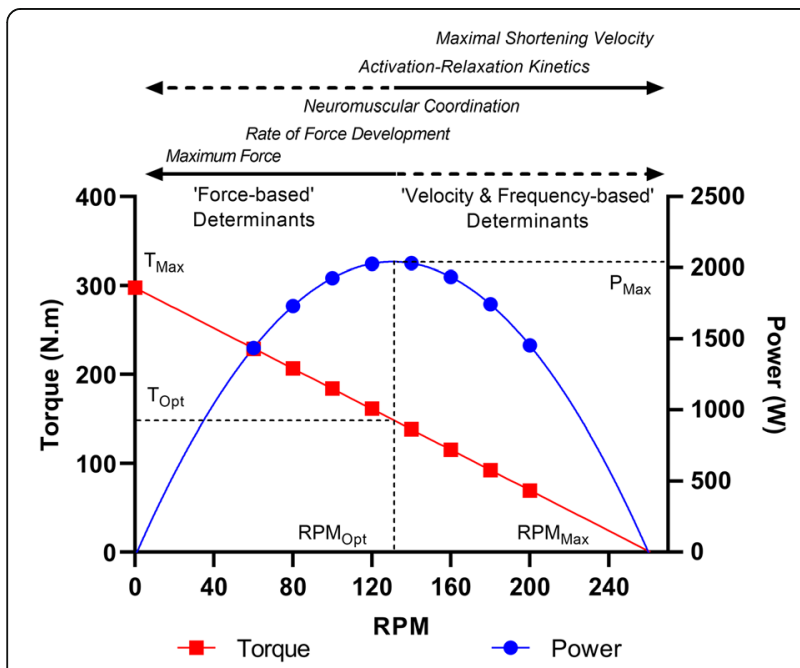

Fig. 2 The torque- and power-pedalling rate relationship, parameters and determinants. The torque- and power-pedalling rate relationship is determined by an interaction of 'force-based' and 'velocity \& frequency-based' factors. It should be noted that all determinants influence torque and power production at most pedalling rates experienced within sprint cycling; however, the relative importance of a given factor is pedalling rate dependent. Abbreviations: $\mathrm{P}_{\mathrm{Max}}$, maximum power; $\mathrm{RPM}_{\text {Max }}$ maximum pedalling rate; $\mathrm{RPM}_{\mathrm{Opt}}$ optimum pedalling rate (i.e. optimal frequency); $T_{\text {Max }}$ maximum torque; $T_{\text {Opt }}$ optimum torque power production via a maximal unloaded shortening velocity that is 3-5 times faster than slow twitch fibres [28, 77-80]. Higher maximal shortening velocities in type II fibres are accompanied by sarcoplasmic reticulum $\mathrm{Ca}^{2+}$ handling kinetics and MyHC contractile machinery that allow faster rates of ATP hydrolysis, excitationcontraction coupling, and cross-bridge cycling [81-86]. Fast twitch fibres can therefore produce more force and power than slow twitch fibres at any given shortening velocity, with the effects being magnified with increasing shortening velocity [83]. In addition, for a given fibre type, fibre shortening velocity is proportional to its length, or number of sarcomeres in series [87]. All else being equal (e.g. muscle cross-sectional area), muscles that have longer fibre lengths have higher shortening maximal velocities, and therefore, a greater capacity to produce force and power at a given shortening velocity $[28,88,89]$.

As pedalling rate increases during cycling, a greater proportion of the duty cycle becomes occupied by the processes of activation and relaxation, and therefore the role of activation-relaxation kinetics becomes increasingly critical to maximising positive work and minimising negative work [53, 56, 59, 61, 71, 90, 91]. For example, when cycling at $120 \mathrm{rpm}$, a full pedal revolution will take $500 \mathrm{~ms}$, thus providing $250 \mathrm{~ms}$ for the shortening contraction to generate force. Even if rates of force development are high (e.g. due to high levels of neural drive and a brief electromechanical delay) [75], the minimum time required to activate and relax muscle will compromise the attainment of maximum force [6], and the total work that can be produced during a pedal cycle [57]. The minimum time required to deactivate or relax muscle may be 4-6 times longer than that required to activate muscle [53, 90, 92-94]. Accordingly, unrealised work resulting from time required to relax muscle is greater than that resulting from time to activate muscle [59]. Therefore, at most pedalling rates obtained within sprint cycling, the average force production over the pedal cycle will be substantially constrained by activation-relaxation kinetics [57], with relaxation kinetics being the more prominent limiting factor [59]. $\mathrm{Ca}^{2+}$ handling kinetics and cross-bridge cycling rates are the primary determinants of activation-relaxation kinetics [56, 90, 91, 95], and are primarily fibre-type dependent [83]. As noted, type II fibres are known to have faster $\mathrm{Ca}^{2+}$ handling and $\mathrm{MyHC}$ contractile machinery than type I fibres [81-86] allowing faster shortening velocities, and rates of force development and relaxation [68, $84,86,96]$. In addition, series elastic component stiffness will influence the electromechanical delay and the speed at which muscle force can be transferred to the pedal following muscle contraction [75, 97, 98].

Whilst neural drive influences the rate and magnitude of force production at any given pedalling rate during 
sprint cycling [75], the ability to effectively coordinate the lower body synergists may limit the ability to produce power at pedalling rates above optimal cadence [99]. Maximal muscle activation does not appear to be influenced by pedalling rate, but an earlier EMG onset of the hip and knee extensors within the pedal cycle occurs with increasing pedalling rate [51, 52], which may reflect a coordinative attempt to account for the reduced timeframe available to produce force [56, 90]. Additional coordinative adjustments at high pedalling rates may include a preferential recruitment of fast twitch motor units [100], and an earlier deactivation of slow twitch motor units [101], to minimise the detrimental effects of slower activation-relaxation kinetics on power production. Nonetheless, disruptions in limb and muscle coordination consistently occur at or shortly after optimal cadence [102]. An increase in ineffective force and unrealised work at high pedalling rates indicates that coordinative adjustments cannot successfully overcome the limitations imposed by minimum timeframes required for activation and relaxation, and there is a limit to how well the limbs can be coordinated to effectively orient force at high movement frequencies [26, 52, 99, 102].

\section{Developing Maximal Cycling Power}

Increasing maximal cycling power production is readily achievable through various training modalities that address underlying force-, velocity- and frequency-based neuromuscular properties [25, 103-107] (Table 1). It seems that force-based (e.g. maximum force and rate of force development) determinants of power production are more modifiable with training than velocity- and frequency-based (e.g. maximal shortening velocity, activation-relaxation kinetics and neuromuscular coordination) determinants [23, 25], and so, the powerpedalling rate relationship may be raised with training, but rightward shifts are less common. It is for this reason that elite sprint cyclists tend to exhibit relatively homogeneous velocity-based capabilities but heterogeneous force and power producing capabilities [23], highlighting the importance of strength training in the long-term development of maximal cycling power [25, 108]. Nonetheless, velocity- and frequency-based capabilities remain critical in determining the limits of the power-pedalling rate relationship [25], and training should address the range of force- and velocity-based capabilities to maximise improvements in sprint cycling power production $[25,108,109]$.

A higher capacity to produce maximum force does not guarantee high rates of force development or power production $[110,111]$, but due to the linear force-velocity relationship, an increase in maximal force indicates a greater capacity to produce force and power across a range of movement velocities [104, 109, 112, 113].
Therefore, it is unsurprising that maximum force and rate of force development exhibit strong associations with maximal cycling torque and power production in trained sprint cyclists [114, 115]. Increased maximum force is underpinned by muscle morphological (e.g. increased muscle cross-sectional area), architectural (e.g. increased pennation angle and decreased fascicle length) and neural (e.g. increased motor unit recruitment, rate coding and synchronisation) adaptations [28, 116, 117], which can be readily achieved through traditional strength training methods [112, 113, 118, 119]. Accordingly, traditional strength training remains a cornerstone of a sprint cyclists training regime [25].

Whilst novice (i.e. without a resistance training background) athletes can experience increases in strength and power in response to non-specific strength training stimuli $[108,112,120]$, a foundation of maximum strength achieved through strength training is probably optimal in maximising long-term power development $[108,121]$. Improvements in maximum force become increasingly difficult to achieve as strength levels increase and may translate less directly to improvements in highvelocity force production [108], indicating the need for greater specificity (e.g. movement pattern and velocity) and/or variation (e.g. via varied prescription or the introduction of novel methods) in training stimuli to achieve further increases in maximal power [112, 118, 121, 122]. For example, novel strategies such as velocity-based training [123, 124], eccentric training [125-128], isometric training [74] and electromyostimulation [129, 130] incorporated alongside traditional strength training may be effective in inducing further increases in maximal and high-velocity force production (e.g. via enhanced neural adaptations, preferential fast twitch fibre hypertrophy and increased muscle-tendon unit stiffness) in strength trained individuals. Upon the attainment of high levels of maximum strength, explosive strength training may become increasingly important to achieve further increases in maximal power $[108,110,111,121]$ via neural adaptations that increase the magnitude and rate of force development at high movement velocities $[75,108$, 109, 131-134]. Excessive attention to heavy and slow strength training in the absence of explosive movements seems to be sub-optimal for power production [110], especially during cyclic tasks at high movement frequencies due to a slowing of relaxation kinetics $[135,136]$.

Whilst a foundation of traditional strength training will benefit maximal cycling power, there is a clear biomechanical discrepancy between the acyclic bilateral movements (e.g. squats and Olympic lifts) often implemented in practice and the cyclic unilateral demands of sprint cycling. Cycling-based force and power training likely remain critical to maximising the transfer of general neuromuscular strength and power to specific sprint 
Table 1 The effects of various training methods on the determinants of maximal muscular power, sustained power production during brief maximal efforts, and rates of recovery

\begin{tabular}{|c|c|c|c|c|c|c|c|}
\hline Determinants & $\begin{array}{l}\text { Maximum } \\
\text { force }\end{array}$ & $\begin{array}{l}\text { Rate of force } \\
\text { development }\end{array}$ & $\begin{array}{l}\text { Neuromuscular } \\
\text { coordination }\end{array}$ & $\begin{array}{l}\text { Activation- } \\
\text { relaxation } \\
\text { kinetics }\end{array}$ & $\begin{array}{l}\text { Maximum } \\
\text { shortening } \\
\text { velocity }\end{array}$ & $\begin{array}{l}\text { Fatigue } \\
\text { resistance }\end{array}$ & $\begin{array}{l}\text { Muscle } \\
\text { oxidative } \\
\text { capacity }\end{array}$ \\
\hline Relevant mechanisms & $\begin{array}{l}\text { - Muscle CSA } \\
\text { - MyHC Ila/x } \\
\text { area ratio } \\
\text { - MyHC Ila/x } \\
\text { composition } \\
\text { (positive } \\
\text { effect) } \\
\text { - Neural drive } \\
\text { - Muscle } \\
\text { architecture }\end{array}$ & $\begin{array}{l}\text { - Maximum } \\
\text { force } \\
\text { - Neural drive } \\
\text { - MyHC Ila/x } \\
\text { area ratio } \\
\text { - MyHC Ila/x } \\
\text { composition } \\
\text { (positive } \\
\text { effect) } \\
\text { - MTU stiffness }\end{array}$ & $\begin{array}{l}\text { - Magnitude of } \\
\text { muscle } \\
\text { activation } \\
\text {-Timing of } \\
\text { muscle } \\
\text { activation and } \\
\text { relaxation }\end{array}$ & $\begin{array}{l}\text { - MyHC Ila/x } \\
\text { composition } \\
\text { (positive effect) } \\
\text {-Sarcoplasmic } \\
\text { reticulum } \\
\text { structure and } \\
\text { function }\end{array}$ & $\begin{array}{l}\text { - MyHC Ila/x } \\
\text { composition } \\
\text { (positive } \\
\text { effect) } \\
\text { - Muscle } \\
\text { architecture }\end{array}$ & $\begin{array}{l}\text { - MyHC Ila/x } \\
\text { composition } \\
\text { (negative effect) } \\
\text {-Anaerobic } \\
\text { substrate } \\
\text { availability and } \\
\text { enzyme activity } \\
\text {-Metabolite } \\
\text { buffering capacity } \\
\text {-Pain tolerance }\end{array}$ & $\begin{array}{l}\text { - Muscle CSA } \\
\text { (negative } \\
\text { effect) } \\
\text { - MyHC IIa/x } \\
\text { composition } \\
\text { (negative } \\
\text { effect) } \\
\text { - Mitochondrial } \\
\text { and capillary } \\
\text { density } \\
\text {-Oxidative } \\
\text { enzyme activity }\end{array}$ \\
\hline
\end{tabular}

Training methods for maximal power

\begin{tabular}{|c|c|c|c|c|c|c|c|}
\hline $\begin{array}{l}\text { Maximum strength } \\
\text { training }\end{array}$ & $\uparrow \uparrow \uparrow$ & $\uparrow \uparrow$ & - & $\downarrow$ & $\downarrow$ & $\uparrow$ & $\downarrow(?)$ \\
\hline $\begin{array}{l}\text { Explosive strength } \\
\text { training }\end{array}$ & $\uparrow \uparrow$ & $\uparrow \uparrow \uparrow$ & - & $-(?)$ & $-(?)$ & $\uparrow$ & - \\
\hline $\begin{array}{l}\text { Eccentric strength } \\
\text { training }\end{array}$ & $\uparrow \uparrow \uparrow$ & $\uparrow \uparrow \uparrow(?)$ & - & $\uparrow(?)$ & $\uparrow(?)$ & $\downarrow(?)$ & $\downarrow(?)$ \\
\hline $\begin{array}{l}\text { Isokinetic strength and } \\
\text { power training }\end{array}$ & $\uparrow \uparrow(?)$ & $\uparrow \uparrow \uparrow(?)$ & $\uparrow \uparrow \uparrow(?)$ & - & - & $\uparrow \uparrow$ & $\uparrow$ \\
\hline $\begin{array}{l}\text { Specific cycling } \\
\text { strength and power } \\
\text { training (track or } \\
\text { ergometer) }\end{array}$ & $\uparrow \uparrow$ & $\uparrow \uparrow \uparrow$ & $\uparrow \uparrow \uparrow$ & $-(?)$ & $-(?)$ & $\uparrow$ & $\uparrow$ \\
\hline \multicolumn{8}{|c|}{ Training methods for sustained power and rates of recovery } \\
\hline $\begin{array}{l}\text { Sprint interval 'Speed- } \\
\text { Endurance' training } \\
\text { (track or ergometer) }\end{array}$ & - & $\uparrow$ & $\uparrow \uparrow$ & - & - & $\uparrow \uparrow$ & $\uparrow$ \\
\hline $\begin{array}{l}\text { Long interval training } \\
\text { (ergometer or road) }\end{array}$ & $\downarrow \downarrow$ & $\downarrow \downarrow$ & - & $\downarrow \downarrow$ & $\downarrow \downarrow$ & $\uparrow \uparrow$ & $\uparrow \uparrow \uparrow$ \\
\hline $\begin{array}{l}\text { Endurance training } \\
\text { (ergometer or road) }\end{array}$ & $\downarrow \downarrow$ & $\downarrow \downarrow$ & - & $\downarrow \downarrow$ & $\downarrow \downarrow$ & $\uparrow$ & $\uparrow \uparrow \uparrow$ \\
\hline $\begin{array}{l}\text { Repeated sprint } \\
\text { training in hypoxia }\end{array}$ & - & $\downarrow(?)$ & - & $\downarrow(?)$ & $\downarrow(?)$ & $\uparrow \uparrow$ & $\uparrow \uparrow \uparrow$ \\
\hline $\begin{array}{l}\text { Single legged interval } \\
\text { training }\end{array}$ & - & $\downarrow(?)$ & - & $\downarrow(?)$ & $\downarrow(?)$ & $\uparrow \uparrow$ & $\uparrow \uparrow \uparrow$ \\
\hline
\end{tabular}

Abbreviations: CSA cross-sectional area, MTU muscle-tendon unit, MyHC myosin heavy chain isoform. Training effect key: $\uparrow \uparrow \uparrow$, highly positive; $\uparrow \uparrow$, moderately positive; $\uparrow$, possibly positive effect; $\downarrow \downarrow \downarrow$, highly negative; $\downarrow \downarrow$, moderately negative; $\downarrow$, possibly negative; -, neither positive nor negative; (?), effect uncertain

cycling power production. Isokinetic cycling may be an especially effective means to maximise the transfer of general strength to cycling-specific force and power production at a given pedalling rate [105]; however, evidence supporting the utility of this modality is scarce. Alternatively, recent evidence indicates that cyclingspecific isometric training can increase maximum cycling force and power production in elite sprint cyclists [74]. Resistive forces are readily modifiable within track cycling (e.g. via the manipulation of gear ratios, inertia, gravitational and aerodynamic forces), and so any given portion of the power-pedalling rate relationship may be addressed within specific training. Specific sprint cycling training utilising short duration efforts at high pedalling rates (e.g. $~ 160-210 \mathrm{rpm}$ ) seems to be effective in increasing power output at high pedalling rates in the absence of changes to $\mathrm{MyHC}$ composition and $\mathrm{Ca}^{2+}$ handling kinetics [104], potentially by improving neuromuscular coordination $[51,52,99,104]$. Collectively, maximal and explosive strength training in conjunction with specific cycling power training can improve forcebased properties and raise the torque- and powerpedalling rate relationship.

Improvements in velocity- and frequency-based capabilities may not be largely attainable independent of changes to $\mathrm{MyHC}$ composition [104, 137], and so are less responsive to training [25]. Shifting between fast twitch sub-fibre types (i.e. MyHC IIa $\leftrightarrow$ IIx) can occur 
in response to training and detraining [138-142], but it is less clear if shifts between type I and type II fibres occur in humans [79, 143-145]. Sprint training does seem to induce a bidirectional shift (i.e. MyHC I $\rightarrow$ IIa $\leftarrow$ IIx) with the slowest and fastest $\mathrm{MyHC}$ isoforms converging towards an intermediate isoform [146-148]. A period of detraining following resistance training may also induce an 'overshoot' of MyHC IIx composition above pre-training levels, largely at the expense of MyHC IIa fibres [141, 146], which has been associated with an increased maximal shortening velocity and highvelocity force production [149]. However, the detrimental effects of detraining on maximal force, power and fatigue-resistance [149-151], could possibly outweigh the positive effects of improved high-velocity contractile performance in trained sprint cyclists. Alternatively, some evidence indicates that eccentric training can increase MyHC IIx composition at the expense of MyHC I fibres [152], and indeed chronic eccentric training has been demonstrated to increase cycling power [153]. Irrespective of the possibility for changes in MyHC composition, eccentric training can induce a preferential hypertrophy of fast twitch fibres [125]. Whilst it is not clear if preferential fast twitch fibre hypertrophy influences maximum shortening velocity or activationrelaxation kinetics, an increase in the fast twitch to slow twitch area ratio may increase high-velocity force production $[132,136,154,155]$. It is also plausible that eccentric training could increase maximal shortening velocity and power production at high pedalling rates via an increase in muscle fascicle length [89, 125], although this supposition has yet to be experimentally demonstrated.

Finally, sarcoplasmic reticulum volume density is a primary determinant of relaxation rates and high movement frequencies across species [156]. Therefore, veryhigh frequency training (e.g. on short-crank ergometers) has been used in practice to specifically induce quantitative and qualitative changes in sarcoplasmic reticulum excitation-contraction coupling machinery [157]. Nonetheless, at present, there is little evidence supporting the efficacy of this modality in modifying sarcoplasmic reticulum properties, although it may benefit power production at high pedalling rates (e.g. at or above optimal cadence) via improvements in neuromuscular coordination [104]. Whilst there may be little experimental evidence identifying changes in velocity- or frequencybased capabilities, it is important to note that small improvements have been reported over the career of elite sprint cyclists [25]. Such improvements may not dramatically improve maximal power production; however, it may be speculated that maintaining or subtly improving these qualities in the presence of extensive strength, sprint interval and endurance training (the 'Developing fatigue resistance and muscle oxidative capacity' section) may mitigate a shift towards a slower phenotype, and thus optimise long-term sprint cycling performance.

\section{Sustaining Maximal Power Production}

Fatigue-Related Impairments to Maximal Cycling Power

Maximal power is highly repeatable and fatigue resistant if there is a sufficient recovery duration between efforts $[6,158,159]$. However, the duration of most sprint cycling events requires sustained maximal efforts of $\sim 15-60$ s. Power production during human locomotion follows an exponentially decaying relationship with effort duration (Fig. 3) due to fatigue-related impairments in neuromuscular performance [20,160-162]. During sustained maximal efforts power production declines from a maximal output at $\sim 3 \mathrm{~s}$ to a near steady state after $\sim 300 \mathrm{~s}[160,162]$. The power loss (i.e. also referred to as the 'fatigue index') during brief (i.e. 25-30 s) maximal cycling efforts has been shown to be $\sim 30-60 \%$, or $\sim 1-2 \%$ per s ${ }^{-1}[46,68,155,163,164]$, concomitant with a progressive downregulation of agonist muscle activation $[165,166]$. A higher rate of power loss is evident with increasing pedalling rate [46, 68, 163, 164, 167], which likely reflects a leftward shift of the power-pedalling rate relationship with fatigue [168].

The high mechanical demands (i.e. necessitating the recruitment of fatigable fast twitch fibres) during sprint cycling places a substantial reliance on anaerobic energy production [169-171], and induces a progressive inhibition of contractile performance [20, 172, 173]. This is reflected in an altered power-pedalling rate relationship in the fatigued state [168, 174]. Fatigued fibres exhibit impairments in maximal force $[175,176]$, maximal shortening velocity $[177,178]$ and relaxation rate $[179$

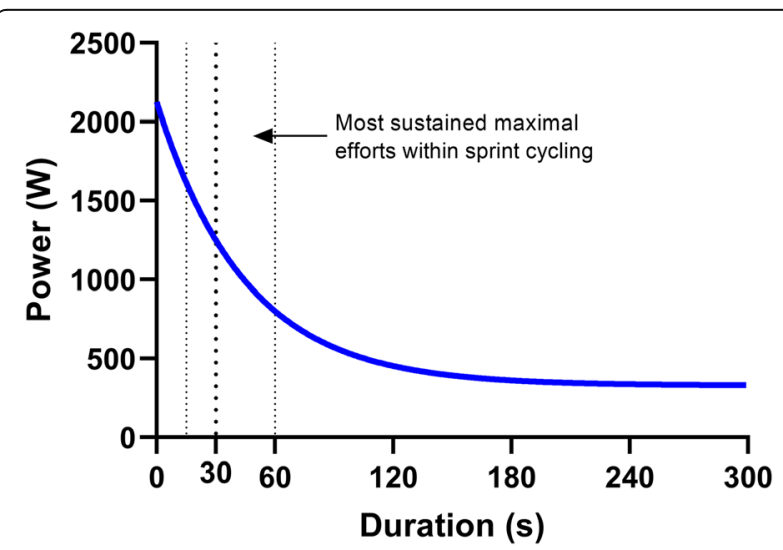

Fig. 3 The power-duration relationship. Most sustained maximal efforts during sprint cycling last between $\sim 15$ and $\sim 60 \mathrm{~s}$, and so are characterised by a rapid exponential decay in power production. Extensive research into the mechanisms of sustained power production during brief maximal (i.e. 'all-out') efforts has utilised a 30 s (i.e. 'Wingate') exercise model 
181]. Maximum torque and maximum pedalling rate appear to be affected by fatigue at similar rates, collectively contributing to power loss [174], although unpublished data indicates that impairments in maximal force contributes most to power loss at low cycle frequencies whilst impairments in relaxation rates lead to the production of negative work and power loss at high frequencies (Link and Martin, In Review). A downwards leftwards shift (and possibly an increased curvature of the force-velocity relationship) is observed with fatigue (Fig. 4) $[174,175,178]$. Accordingly, impairments in both maximum power (e.g. 45\%) and optimal pedalling rate (e.g. $\sim 31 \%$ ) are seen following $\sim 30 \mathrm{~s}$ of maximal cycling at the non-fatigued optimal pedalling rate [168]. The altered power-pedalling rate relationship may reflect the specific recruitment and fatigue of fast twitch fibres during maximal high-velocity tasks [68, 163, 182], and a subsequent reliance on fatigue-resistant slow twitch fibres to produce power [180], although this supposition remains to be experimentally corroborated.

Fatigue during brief maximal cycling seems to be largely peripheral rather than central in origin $[143,163$, 183], although an interaction of mechanisms cannot be discounted [165, 184, 185]. Rates of ATP resynthesis per se may not limit performance during maximal tasks of $\sim 60 \mathrm{~s}$ or less $[20,160,161]$, rather contractile performance is downregulated when energy demands exceed rates of energy resynthesis [186]. Rates of high energy phosphate (i.e. ATP and creatine phosphate) depletion and inosine monophosphate (IMP) accumulation are indeed high during brief maximal cycling at high pedalling

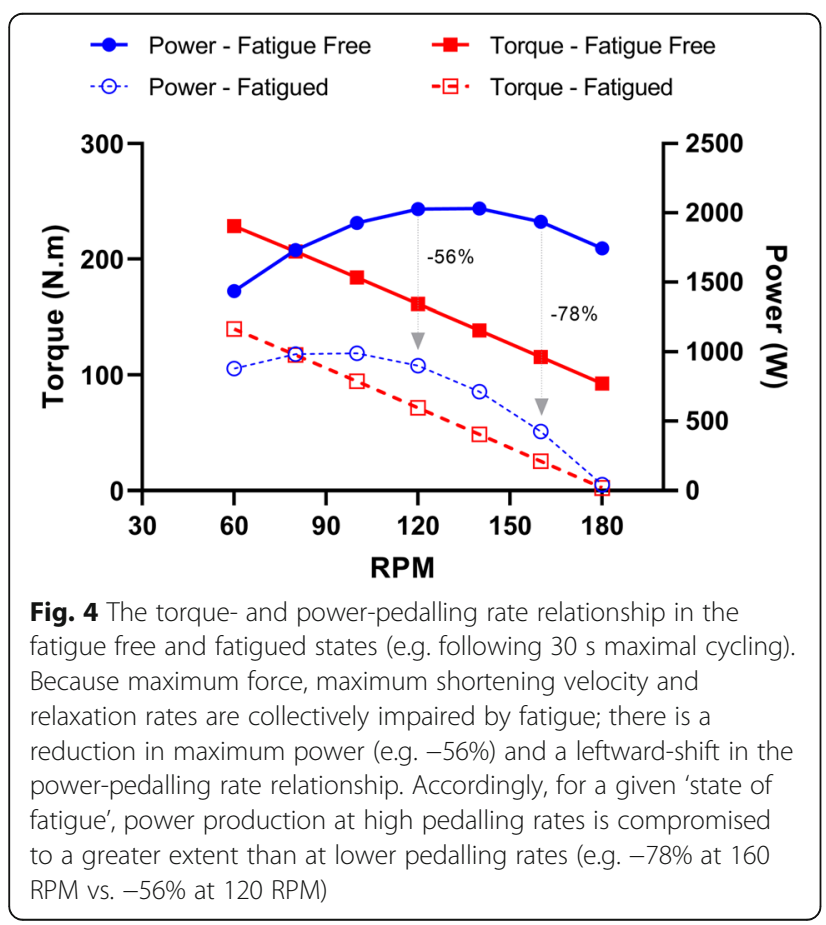

rates, especially in fast twitch fibres [187, 188], indicating a high degree of myocellular energetic stress, but an ensuing rigour state does not occur, and so excitationcontraction coupling mechanisms may be downregulated to avert a 'metabolic catastrophe' [186]. The higher rates of ATP hydrolysis and glycolysis in fast twitch fibres during maximal cycling likely results in a faster accumulation of metabolic by-products implicated in fatigue [83, 187, 189, 190].

The accumulation of the metabolites inorganic phosphate $\left(\mathrm{P}_{\mathrm{i}}\right)$, hydrogen $\left(\mathrm{H}^{+}\right)$and adenosine diphosphate (ADP) can interfere (i.e. directly or via a reduction of cytosolic $\mathrm{pH}$ ) with glycolytic enzyme (e.g. phosphofructokinase) activity, myofilament sensitivity to $\mathrm{Ca}^{2+}$, crossbridge kinetics (i.e. actomyosin binding number, force and cycling rate) and sarcoplasmic reticulum $\mathrm{Ca}^{2+}$ release and reuptake kinetics [95, 180, 184, 189-193]. These effects are especially pronounced within fast twitch fibre populations [194-196], and result in impaired force production, shortening velocity and rates of relaxation. Metabolite accumulation in the interstitial space also stimulates group III and IV chemo- and nociceptive muscle afferents [184], which may directly decrease motor output via inhibition of motor neuron recruitment and firing, and indirectly via a downregulation of central motor drive accompanied by sensations of discomfort or pain $[162,185,191]$.

\section{The Importance of Aerobic Fitness Within Sprint Cycling}

In many instances within sprint cycling maximum sustained power must be produced following a period of submaximal work, and often repeatedly following recovery periods ranging from minutes to hours. The magnitude of fatigue incurred from preceding submaximal work will be directly proportional to the intensity and duration of the bout, with rates of fatigue increasing with the relative reliance on anaerobic energy metabolism, as defined by the intensity relative to the maximum intensity that can be sustained by oxidative phosphorylation (i.e. critical power) [20, 160-162]. It appears that there is an approximately fixed amount of work (i.e. $W^{\prime}$ ) that can be completed above the critical power before task failure occurs $[19,162]$. $W$ ' seems to represent a combination of available biochemical stores and/or the maximal tolerable limit of metabolite-induced peripheral fatigue [197-200], with a depletion rate that is intensitydependent [162]. Therefore, a higher critical power (e.g. via enhanced muscle oxidative capacity) will increase the range of submaximal intensities at which $W^{\prime}$ can be spared, thus mitigating fatigue-related impairments to subsequent maximal efforts.

The recovery of $W^{\prime}$, which may reflect the resynthesis of high energy phosphate stores and clearance of metabolites, appears to be curvilinear with much of the 
repletion occurring within $\sim 60 \mathrm{~s}$ [199]. Muscle oxidative capacity (i.e. capillary density, mitochondrial content and oxidative enzyme activity) is likely the most important factor influencing the recovery time course (i.e. encompassing metabolite removal, $\mathrm{PCr}$ resynthesis and restoration of cytosolic $\mathrm{pH}$ ) following maximal fatiguing efforts [187, 199, 201, 202], although muscle carnosine content also predicts the rate of recovery of $W^{\prime}$ following hard exercise [199], presumably via an enhanced intramyocellular buffering capacity [203]. Muscle oxidative capacity tends to be lower in fast versus slow fibres [83, 204], and accordingly, the rate of recovery in these fibres is slower [143].

\section{Developing Fatigue Resistance and Muscle Oxidative Capacity}

Increasing maximal power production is probably the most effective means to improve sustained power during brief maximal efforts via an overall increase of the power-duration relationship [107, 143, 205-208]. Indeed, reductions in rates of fatigue during $\sim 30-45 \mathrm{~s}$ maximal cycling efforts seem to be difficult to achieve with training, even in the presence of physiological adaptations that would be expected to improve fatigue resistance [146, 147, 207, 209-211]. Nonetheless, addressing fatigue resistance through track- and ergometer-based sprint interval training (i.e. 'speed-endurance' training involving maximal sustained efforts with complete recovery) is probably still necessary to maximise sustained power production [212, 213]. It could be speculated that specifically addressing fatigue resistance following improvements in maximum power may be necessary to attenuate possible increased rates of substrate depletion and metabolite accumulation arising from enhanced metabolic and mechanical power output. An additional advantage of sprint interval training is an improved muscle oxidative capacity [213, 214], although specific aerobic training (e.g. endurance and other interval training variations) may still be necessary to ensure a sufficiently developed muscle oxidative capacity [213].

Improvements in fatigue resistance from sprint interval training could plausibly involve changes to enzyme activity, substrate stores and enhanced buffering of fatiguing metabolites [146], which may be reflected in an increase in markers of glycolytic flux (e.g. higher lactate production) for a given sprint cycling bout without any changes to local pH values [207, 211]. Sprint interval training seems to increase glycolytic enzyme activity which may increase maximal rates of glycolytic energy flux [107, 146, 209-211]. Whilst it may be possible to improve rates of anaerobic energy supply, it is not clear if supply is a rate limiting step to performance and rather energy supply rates seem to be largely demand-driven [20]. Attenuating the metabolite-induced downregulation of contractile performance through enhanced buffering may be the most relevant mechanism for improving fatigue-resistance with sprint interval training. The accumulation of metabolic by-products remains an unavoidable consequence of high rates of anaerobic energy supply and so it is not possible to entirely ameliorate the subsequent detrimental effects on contractile function. However, it seems $\mathrm{pH}$ regulation via $\mathrm{H}^{+}$efflux and buffering is a reasonably modifiable avenue for performance enhancement [211]. Traininginduced improvements in $\mathrm{pH}$ regulation may be related to adaptations to membrane transport systems for cytosolic $\mathrm{H}^{+}$efflux (i.e. to mitochondria or extracellular buffers) [193, 215-218]. Monocarboxylate transporters (MCT1 and MCT4) account for most of the myocellular proton efflux during high intensity efforts [193], and are highly responsive to training and detraining [218], although less so in sprint-trained individuals [213].

It is possible that an improved tolerance to acidosisrelated stimulation of type III-IV muscle afferents via repeated exposures could allow a better maintenance of motor drive in the presence substantial discomfort [191]. Whilst pedalling rate markedly influences rates of power loss within sprint cycling, little evidence is available identifying the optimal pedalling rate within sprintinterval training. It has been a common practice within elite sprint cycling to undertake training at very high pedalling rates (e.g. small gear track, ergometer or roller sprints) purportedly to elicit fatigue resistance specifically within the excitation-contraction coupling machinery. In contrast, the recent trend for larger competition gearing has resulted in faster competition times [219], and the practice of sprint interval training performed at low pedalling rates (e.g. large gear track or ergometer sessions) to elicit a form of 'strength-endurance' that could attenuate fatigue and power loss during sprint cycling. Based upon the principle of specificity, it seems intuitive to assume that the pedalling rate used within sprint interval training would mediate a particular adaptive response. However, this supposition has yet to be systematically corroborated. Indeed, a variety of training modalities, each intended to improve a specific limiting physiological mechanism may be the optimal approach [220].

Finally, improvements in muscle oxidative capacity can be readily achieved via traditional endurance and long interval training [221, 222]. However, excessive attention to this form of training may compromise the development of maximal strength and power [223]. Endurance training may directly downregulate rates of protein synthesis and inducing a shift towards more fatigueresistant but slower MyHC (e.g. IIx $\rightarrow$ IIa $\rightarrow$ I) isoforms $[79,145,146,224]$, or compromise strength and power training via residual fatigue and/or substrate depletion [225]. Therefore, training to improve muscle oxidative 
capacity needs to be carefully dosed to mitigate potentially detrimental interference effects. Alternatively, novel training strategies may be implemented to more efficiently (i.e. achieving a given adaptive signal for a smaller dosage) elicit muscle oxidative adaptations. Emerging evidence indicates that relatively low volume short-term repeated sprint training (i.e. a protocol which elicits fast muscle fibre recruitment and high rates of oxidative flux) performed in hypoxia can induce nonhaematological muscle adaptations associated with enhanced muscle glycolytic and oxidative capacities [226, 227]. Specifically, this form of training has been found to upregulate oxidative and glycolytic enzyme activity, muscle buffer content and mitochondrial and capillary density via an activation of the HIF- $1 \alpha$ and HIF- $2 \alpha$ signalling cascades [228-230], Similarly, single leg cycling is a training strategy which elicits an increased mechanical workload and local perfusion per leg during interval training versus double leg cycling, and subsequently has been shown to induce greater increases in muscle oxidative capacity in endurance trained cyclists [231]. Although it is not clear if the attenuated central stimulation from this method may compromise the maintenance of at least a minimum threshold of central (e.g. pulmonary diffusion capacity, cardiac output and oxygen carrying capacity) aerobic qualities. Further research is necessary to clarify the efficacy of hypoxic training and single leg cycling in improving muscle oxidative capacity in trained sprint cyclists.

\section{Conclusion}

Maximal muscular power during cyclic contractions is limited by force-velocity and activation-relaxation characteristics, fatigue resistance and coordination amongst joints and muscles [26, 57]. At low cycle frequencies, maximal force and rate of force development may be most critical to power production [51], and as frequency increases to optimal frequency and beyond, maximal shortening velocity, activation-relaxation kinetics (especially relaxation) and muscle coordination likely play an increasingly prominent role [52]. Sprint cyclists operate at the edge of human potential with regards to maximal muscular power production, and those that exhibit the highest levels of maximum and sustained power relative to their body mass and aerodynamic drag will tend to be the fastest [1, 23]. Cycling power is a product of pedalling rate and the pedal force (directed normal to the crank) or torque (at the crank) generated from coordinated actions of the hip, knee and ankle extensors [25, 46]. Force-based determinants of maximum power are highly trainable [108], and traditional strength training combined with cycling-based strength and power training remains the foundation for long term powerdevelopment within sprint cycling. Velocity- and frequency-based determinants may not be highly modifiable with training independent of changes in $\mathrm{MyHC}$ composition [25]. Maximal efforts may need to be sustained for $\sim 15-60$ s or longer during sprint cycling competition, but a rapid and progressive fatigue-related power loss is observed almost immediately after maximum power is attained [20]. The fatigued state is characterised by impairments in force-velocity properties and activation-relaxation kinetics, and so a suppression and leftward shift of the power-pedalling rate relationship occurs [168]. Increasing maximum power and raising the power-duration relationship is probably the most effective means of increasing sustained power during brief maximal tasks. It is unclear if rates of fatigue can be markedly improved with training even in the presence physiological adaptations associated with fatigueresistance, although sprint interval training may still be necessary to optimise performance [213]. Traditional endurance training methods used to develop muscle oxidative capacity are known to interfere with maximal power development [145], and so the modality and dosage needs to be carefully considered. It may be postulated that a predominance of MyHC IIa fibres in particular and in combination with longer muscle fascicles (i.e. for a higher maximal shortening velocity) for a given muscle cross-sectional area may reflect an optimised phenotype for the simultaneous expression of maximal power, fatigue-resistance and muscle oxidative capacity [17, 89 , 145], and therefore, sprint cycling performance. These insights can allow scientists and practitioners alike to better understand the mechanistic basis of maximal muscular power production, and subsequently, advance the limits of human potential within a range of athletic and health-related disciplines through the application of appropriate training strategies.

\section{Acknowledgements}

Not applicable.

Authors' contributions

JD conceptualised the manuscript, reviewed the literature and completed the first draft. JD, AR and JCM edited the draft and completed the final manuscript. The author(s) read and approved the final manuscript.

Funding

No sources of funding were used to assist in the preparation of this article.

Availability of data and materials

Not applicable.

\section{Declarations}

Ethics approval and consent to participate Not applicable.

Consent for publication

Not applicable. 


\section{Competing interests}

The authors, Jamie Douglas, Angus Ross, and James C Martin, declare that they have no competing interests.

\section{Author details}

'High Performance Sport New Zealand (HPSNZ), Avantidrome, 15 Hanlin Road, Cambridge 3283, New Zealand. ${ }^{2}$ Cycling New Zealand, Cambridge, New Zealand. ${ }^{3}$ Department of Nutrition and Integrative Physiology, University of Utah, Salt Lake City, UT, USA.

\section{Received: 28 January 2021 Accepted: 29 June 2021} Published online: 15 July 2021

\section{References}

1. Martin JC, Gardner AS, Barras M, Martin DT. Modeling sprint cycling using field-derived parameters and forward integration. Med Sci Sports Exerc. 2006:38(3):592-7.

2. Olds T. Modelling human locomotion: applications to cycling. Sports Med. 2001;31(7):497-509.

3. Olds TS, Norton KI, Craig NP. Mathematical model of cycling performance. J Appl Physiol. 1993;75(2):730-7.

4. Flyger N, Froncioni A, Martin DT, Billaut F, Aughey RJ, Martin JC. Modelling track cycling standing start performance: combining energy supply and energy demand. ISBS Conf Proc Arch. 2013;1(1):1-4.

5. Jeukendrup AE, Craig NP, Hawley JA. The bioenergetics of world class cycling. J Sci Med Sport. 2000;3(4):414-33.

6. Martin JC, Davidson CJ, Pardyjak ER. Understanding sprint-cycling performance: the integration of muscle power, resistance and modelling. Int J Sports Physiol Perf. 2007;2:5-21.

7. Di Prampero PE, Cortili G, Mognoni P, Saibene F. Equation of motion of a cyclist. J Appl Physiol. 1979;47(1):201-6.

8. Capelli C, Schena F, Zamparo P, Monte AD, Faina M, di Prampero PE. Energetics of best performances in track cycling. Med Sci Sports Exerc. 1998; 30(4):614-24.

9. Jeukendrup AE, Martin JE. Improving cycling performance: how should we spend our time and money. Sports Med. 2001;31(7):559-69.

10. Martin JC, Milliken DL, Cobb JE, McFadden KL, Coggan AR. Validation of a mathematical model for road cycling power. J Appl Biomech. 1998;14:276-91.

11. Malizia F, Blocken B. Bicycle aerodynamics: history, state-of-the-art and future perspectives. J Wind Eng Ind Aer. 2020;200:1-30.

12. Bellioli M, Giappino S, Robustelli F, Somaschini C. Drafting effect in cycling investigation by wind tunnel tests. Procedia Engineering. 2016;147:38-43.

13. Crouch TN, Burton D, LaBry ZA, Blair KB. Riding against the wind: a review of competition cycling aerodynamics. Sports Eng. 2017;20:81-110.

14. Craig NP, Norton Kl. Characteristics of track cycling. Sports Med. 2001;31(7): 457-68

15. McLean BD, Parker AW. An anthropometric analysis of elite Australian track cyclists. J Sports Sci. 1989;7(3):247-55.

16. Vandewalle H, Peres G, J. H, Panel J, Monod H. Force-velocity relationship and maximal power on a cycle ergometer: correlation with the height of a vertical jump. Eur J Appl Physiol. 1987;56:650-6.

17. van der Zwaard S, van der Laarse WJ, Weide G, Bloemers FW, Hofmijster MJ, Levels K, et al. Critical determinants of combined sprint and endurance performance: an integrative analysis from muscle fiber to the human body. FASEB J. 2018;32(4):2110-23.

18. de Koning JJ, Bobbert MF, Foster C. Determination of optimal pacing strategy in track cycling with an energy flow model. J Sci Med Sport. 1999; 2(3):266-77.

19. Morton RH. The critical power and related whole-body bioenergetic models. Eur J Appl Physiol. 2006;96:339-54.

20. Bundle MW, Weyand PG. Sprint exercise performance: does metabolic power matter? Exerc Sport Sci Rev. 2012;40:174-82.

21. de Jong J, van der Meijden L, Hamby S, Suckow S, Dodge C, de Koning JJ, et al. Pacing strategy in short cycling time trials. Int J Sports Physiol Perf. 2015;10:1015-22.

22. Foster C, de Koning JJ, Hettinga J, Dodge C, Bobbert M, Porcari JP. Effect of competitive distance on energy expenditure during simulated competition. Int J Sports Med. 2004;25:198-204.

23. Dorel S, Hautier CA, Rambaud O, Rouffet D, Van Praagh E, Lacour JR, et al. Torque and power-velocity relationships in cycling: relevance to track sprint performance in world-class cyclists. Int J Sports Med. 2005;26:739-46.
24. Phillips KE, Hopkins WG. Factors affecting cyclists' chances of success in match-sprint tournaments. Int J Sports Physiol Perf. 2019;14:472-7.

25. Dorel S. Maximal force-velocity and power-velocity characteristics in cycling: assessment and relevance. In: Morin JB, Samozino P, editors. Biomechanics of. Testing and Training: Innovative Concepts and Simple Field Methods; 2018.

26. Dorel S, Couturier A, Lacour JR, Vandewalle H, Hautier C, Hug F. Forcevelocity relationship in cycling revisited: benefit of two-dimensional pedal force analysis. Med Sci Sports Exerc. 2010;42(6):1174-83.

27. Macdougall D, Sale D. The physiology of training for high performance. Oxford University Press: Great Britain, Ashford Colour Press Ltd, Gosport Hampshire; 2014.

28. Cormie P, McGuigan MR, Newton RU. Developing maximal neuromuscular power: part 1 - biological basis of maximal power production. Sports Med. 2011;41(1):17-38.

29. Cronin J, Sleivert G. Challenges in understanding the influence of maximal power training on improving athletic performance. Sports Med. 2005;35(3): 213-34

30. Hautier CA, Linossier MT, Belli A, Lacour JR, Arsac LM. Optimal velocity for maximal power production in non-isokinetic cycling is related to muscle fibre type composition. Eur J Appl Physiol. 1996;74:114-8.

31. Arsac LM, Belli A, Lacour JR. Muscle function during brief maximal exercise: accurate measurements on a friction-loaded cycle ergometer. Eur J Appl Physiol. 1996;74:100-6.

32. Martin JC, Wagner BM, Coyle EF. Inertial-load method determines maximal cycling power in a single exercise bout. Med Sci Sports Exerc. 1997;29(11): 1505-12.

33. Seck D, Vandewalle $H$, Decrops $N$, Monod $H$. Maximal power and torquevelocity relationship on a cycle ergometer during the acceleration phase of a single all-out exercise. Eur J Appl Physiol. 1995;70:161-8.

34. McCartney N, Obminski G, Heigenhauser GJF. Torque-velocity relationship in isokinetic cycling exercise. J Appl Biomech. 1985;58:1459-62.

35. Linossier M-T, Dormois D, Fouquet R, Geyssant A, Denis C. Use of the forcevelocity test to determine the optimal braking force for a sprint exercise on a friction-loaded cycle ergometer. Eur J Appl Physiol. 1996;74:420-7.

36. Gardner AS, Stephens S, Martin DT, Lawton E, Lee H, Jenkins D. Accuracy of SRM and Power Tap power monitoring systems for bicycling. Med Sci Sports Exerc. 2004;36(7):1252-8.

37. Barratt P. SRM torque analysis of standing starts in track cycling (P85). In: Estivalet M, Brisoon P, editors. The Engineering of Sport 7. Paris: Springer Paris; 2008. p. 443-8.

38. Gross M, Gross T. Relationship between cyclic and non-cyclic force-velocity characteristics in BMX cyclists. Sports. 2019;7(232):1-13.

39. Haugen T, Paulsen G, Seiler S, Sandbakk O. New records in human power. Int J Sports Physiol Perf. 2018;13:678-86.

40. Miller AEG, MacDougall JD, Tarnopolsky MA. Sale DG. Gender differences in strength and muscle fiber characteristics Eur J Appl Physiol. 1993:66:254-62.

41. Maud FJ, Shultz BB. Gender comparisons in anaerobic power and anaerobic capacity tests. Br J Sports Med. 1986;20(2):51-4.

42. Staron RS, Hagerman FC, Hikida RS, Murray TF, Hostler DP, Crill MT, et al. Fiber type composition of the vastus lateralis muscle of young men and women. J Histochem Cytochem. 2000;48(5):623-9.

43. Haizlip KM, Harrison BC, Leinwand LA. Sex-based differences in skeletal muscle kinetics and fiber-type composition. Physiol. 2015;30(1):30-9.

44. Martin JC, Farrar RP, Wagner BM, Spirduso WW. Maximal power across the lifespan. J Gerontol. 2000:55A(6):M311-M6.

45. Pearson SJ, Cobbold M, Orrell RW, Harridge SDR. Power output and muscle myosin heavy chain composition in young and elderly men. Med Sci Sports Exerc. 2006;38(9):1601-7.

46. Martin JC, Brown NAT. Joint-specific power production and fatigue during maximal cycling. J Biomech. 2009;42:474-9.

47. Elmer SJ, Barratt PR, Korff T, Martin JC. Joint-specific power production during submaximal and maximal cycling. Med Sci Sports Exerc. 2011;43(10): 1940-7.

48. Reiser RFI, Maines JM, Eisenmann JC, Wilkinson JG. Standing and seated wingate protocols in human cycling. A comparison of standard parameters. Eur J Appl Physiol. 2002;88:152-7.

49. Davidson CJ, Wagner BM, Martin JC. Seated and standing maximal neuromuscular cycling power [Abstract]. Med Sci Sports Exerc. 2004;36(S5):S344.

50. Davidson CJ, Horscroft RD, McDaniel JT, Tomas A, Hunter EL, Grisham JD, et al. The biomechanics of producing standing and seated maximal cycling power [Abstract]. Med Sci Sports Exerc. 2005;37(S5):S393. 
51. Dorel S, Guilhem G, Couturier A, Hug F. Adjustment of muscle coordination during an all-out sprint cycling task. Med Sci Sports Exerc. 2012;44(11):2154-64.

52. Samozino $P$, Horvais $N$, Hintzy F. Why does power output decrease at high pedaling rates during sprint cycling? Med Sci Sports Exerc. 2007;39(4):680-7.

53. Martin JC, Nichols JA. Simulated work loops predict maximal human cycling power. J Exp Biol. 2018:221:1-12.

54. Farina D, Merletti R, Enoka M. The extraction of neural strategies from the surface EMG. J Appl Physiol. 2004;96:1486-95.

55. Kordi M, Folland J, Goodall S, Barratt P, Howatson G. Reliability of traditional and task specific reference tasks to assess peak muscle activation during two different sprint cycling tests. J Electromyog Kinesiol. 2019;46:41-8.

56. Neptune RR, Kautz SA. Muscle activation and deactivation dynamics: the governing properties in fast cyclical human movement performance? Exerc Sport Sci Rev. 2001;29(2):76-81.

57. Martin J. Muscle power: the interaction of cycle frequency and shortening velocity. Exerc Sport Sci Rev. 2007;35(2):74-81.

58. Askew GN, Marsh RL. Optimal shortening velocity (VNmax) of skeletal muscle during cyclical contractions: length-force effects and velocitydependent activation and deactivation. J Exp Biol. 1998;201:1527-40.

59. Caiozzo VJ, Baldwin KM. Determinants of work produced by skeletal muscle: potential limitations of activation and relaxation. Am J Physiol. 1997;273(42): C1049-C56.

60. McDaniel J, Elmer SJ, Martin JC. Limitations of relaxation kinetics on muscular work. Acta Physiol. 2010;198:191-8.

61. Martin JC, Brown NAT, Anderson FC, Spirduso WW. A governing relationship for repetitive muscular contraction. J Biomech. 2000;33:969-74.

62. Neptune RR, Herzog W. Adaptation of muscle co-ordination to altered task mechanics during steady state cycling. J Biomech. 2000;33:165-72.

63. McDaniel J, Behjani NS, Elmer SJ, Brown NAT, Martin JC. Joint-specific power-pedalling rate relationships during maximal cycling. J Appl Biomech. 2014;30:423-30.

64. Edman KA, Elzinga G, Noble Ml. Enhancement of mechanical performance by stretch during tetanic contractions of vertebrate skeletal muscle fibres. J Physiol. 1978;281:139-55.

65. Barratt PR, Korff T, Elmer SJ, Martin JC. Effect of crank length on jointspecific power during maximal cycling. Med Sci Sports Exerc. 2011;43(9): 1689-97.

66. Martin JC, Spirduso WW. Determinants of maximal cycling power: crank length, pedalling rate and pedal speed. Eur J Appl Physiol. 2001;84:413-8.

67. Martin JC, Lamb SM, Brown NAT. Pedal trajectory alters maximal single-leg cycling power. Med Sci Sports Exerc. 2002;34(8):1332-6.

68. McCartney N, Heigenhauser GJF, Jones NL. Power output and fatigue of human muscle in maximal cycling exercise. J Appl Physiol. 1983;55(1): 218-24.

69. Driss T, Vandewalle $H$, Le Chevalier JM, Monod H. Force-velocity relationship on a cycle ergometer and knee-extensor strength indices. Can J Appl Physiol. 2002;27(3):250-62.

70. Davies CTM, Wemyess-Holden J, Young K. Measurement of short term power output: comparisons between cycling and jumping. Ergon. 1984; 27(3):285-96.

71. Bobbert MF, Casius LJR, van Soest AJ. The relationship between pedal force and crank angular velocity in sprint cycling. Med Sci Sports Exerc. 2016; 48(5):869-78.

72. Hintzy F, Belli A, Grappe F, Rouillon JD. Optimal pedalling velocity characteristics during maximal and submaximal cycling in humans. Eur Appl Physiol. 1999;79:426-32.

73. Gardner AS, Martin JC, Martin DC, Barras M, Jenkins DG. Maximal torqueand power-pedaling rate relationships for elite sprint cyclists in laboratory and field tests. Eur J Appl Physiol. 2007;101:287-92

74. Kordi M, Folland J, Goodall S, Menzies S, Patel TS, Evans M, et al. Cyclingspecific isometric resistance training improves peak power output in elite sprint cyclists. Scand J Med Sci Sports. 2020;30(9):1594-604.

75. Maffiuletti NA, Aagaard P, Blazevich AJ, Folland JP, Tillin N, Duchateau J. Rate of force development: physiological and methodological considerations. Eur J Appl Physiol. 2016;116(6):1091-116.

76. Maughan RJ, Watson JS, Weir J. Muscle strength and cross-sectional area in man: a comparison of strength trained and untrained subjects. Br J Sports Med. 1984;18(3):149-57.

77. Shoepe TC, Stelzer JE, Garner DP, Widrick JJ. Functional adaptability of muscle fibers to long-term resistance exercise. Med Sci Sports Exerc. 2003; 35(6):944-51.
78. Maclntosh BR, Herzog W, Suter E, Wiley JP, Sokolosky J. Human skeletal muscle fibre types and force:velocity properties. Eur J Appl Physiol. 1993;67: 499-506.

79. Pette D, Staron RS. Transitions of muscle fiber phenotypic profiles. Histochem Cell Biol. 2001;115(359-372).

80. Bottinelli R, Pellegrino MA, Canepari M, Rossi R, Reggiani C. Specific contributions of various muscle fibre types to human muscle performance: an in vitro study. J Electromyogr Kinesiol. 1999;9:87-95.

81. Bottinelli R, Canepari M, Pellegrino MA, Reggiani C. Force-velocity properties of human skeletal muscle fibres: myosin heavy chain isoform and temperature dependence. J Physiol. 1996;495(2):573-86.

82. Harridge SDR. Plasticity of human skeletal muscle: gene expression to in vivo function. Exp Physiol. 2007;92(5):783-7.

83. Schiaffino S, Reggiani C. Fibre types in mammalian skeletal muscle. Physiol Rev. 2011:91:1447-531.

84. Reggiani C, te Kronnie T. RyR isoforms and fibre type-specific expression of proteins controlling intracellular calcium concentration in skeletal muscles. J Muscle Res Cell Motil. 2006;27:327-35.

85. Lytton J, Westlin M, Burk SE, Shull GE, MacLennan DH. Functional comparisons between isoforms of the sarcoplasmic or endoplasmic reticulum family of calcium pumps. J Biol Chem. 1992;20(15):14483-9.

86. Harridge SDR, Bottinelli R, Canepari M, Pellegrino MA, Reggiani C, Esbjornsson $\mathrm{M}$, et al. Whole-muscle and single-fibre contractile properties and mysoin heavy chain isoforms in humans. Pflugers Arch - Eur J Physiol. 1996:432:913-20.

87. Sacks RD, Roy RR. Architecture of the hind limb muscles of cats: functional significance. J Morphol. 1982;173:185-95.

88. Wickiewicz TL, Roy RR, Powell PL, Perrine JJ, Edgerton VR. Muscle architecture and force-velocity relationships in humans. J Appl Physiol. 1984, 57(2):435-43.

89. Bobbert MF, Casius LJR, van der Zwaard S, Jaspers RT. Effect of vasti morphology on peak sprint cycling power of a human musculoskeletal simulation model. 128. 2020(445-455).

90. van Soest AJ, Casius LJR. Which factors determine the optimal pedalling rate in sprint cycling? Med Sci Sports Exerc. 2000;32(11):1927-34.

91. Neptune RR, Herzog W. The association between negative muscle work and pedaling rate. J Biomech. 1999;32:1021-6.

92. Winters JM, Stark L. Estimated mechanical properties of synergistic muscles involved in movements of a variety of human joints. J Biomech. 1988;21(12) 1027-41.

93. Raasch CC, Zajac FE, Ma B, Levine WS. Muscle coordination of maximumspeed pedaling. J Biomech. 1997;30(6):595-602.

94. Winters JM, Stark L. Analysis of fundamental human movement patterns through the use of in-depth antagonistic muscle models. IEEE Trans Biomed Eng. 1985;32(10):826-39.

95. Westerblad H, Bruton JD, Lannergren J. The effect of intracellular $\mathrm{pH}$ on contractile function of intact, single fibres of mouse muscle declines with increasing temperature. J Physiol. 1997;500(1):193-204.

96. Driss T, Vandewalle H. The measurement of maximal (anaerobic) power output on a cycle ergometer: a critical review. Biomed Res Int. 2013:1-40.

97. Bojsen-Moller J, Magnusson SP, Rasmussen LR, Kjaer M, Aagaard P. Muscle performance during maximal isometric and dynamic contractions is influenced by the stiffness of the tendinous structures. J Appl Physiol (1985) 2005;99:986-94.

98. Watsford ML, Ditroilo M, Fernandez-Pena E, D'Amen G, Lucertini F. Muscle stiffness and rate of torque development during sprint cycling. Med Sci Sports Exerc. 2010;42(7):1324-32.

99. Hodson-Tole EF, Blake OM, Wakeling JM. During cycling what limits maximum mechanical power output at cadences above 120 rpm? Med Sci Sports Exerc. 2020;52(1):214-24

100. Wakeling JM, Uehli K, Rozitis Al. Muscle fibre recruitment can respond to the mechanics of the muscle contraction. J R Soc Interface. 2006:3:533-44.

101. Blake OM, Wakeling JM. Early deactivation of slower muscle fibres at high movement frequencies. J Exp Biol. 2014:217:3528-34.

102. Blake OM, Wakeling JM. Muscle coordination limits efficiency and power output of human limb movement under a wide range of mechanical demands. J Neurophysiol. 2015;114:3283-95.

103. Tofari PJ, Cormack SJ, Ebert TR, Gardner AS, Kemp JG. Comparison of ergometer- and track-based testing in junior track-sprint cyclists. Implications for talent identification and development. J Sport Sci. 2017; 35(19):1947-53. 
104. Harridge SDR, Bottinelli R, Canepari M, Pellegrino M, Reggiani C, Esbjornsson $\mathrm{M}$, et al. Sprint training, in vitro and in vivo muscle function, and myosin heavy chain expression. J Appl Physiol. 1998;84(2):442-9.

105. Konickx E, Van Lemputte M, Hespel P. Effect of isokinetic cycling versus weight training on maximal power output and endurance performance in cycling. Eur J Appl Physiol. 2010;109:699-708.

106. Rudsits B. Assessing, understanding and improving the limits of neuromuscular function on a stationary cycle ergometer. Melbourne, Australia: Victoria University; 2016

107. Linossier M-T, Denis C, Dormois D, Geyssant A, Lacour JR. Ergometric and metabolic adaptation to a 5-s sprint training programme. Eur J Appl Physiol. 1993;67:408-14

108. Cormie P, McGuigan MR, Newton RU. Developing maximal neuromuscular power: part 2 - training considerations for improving maximal power production. Sports Med. 2011;41(2):125-14.

109. Turner AN, Comfort P, McMahon J, Bishop C, Chavda S, Read P et al. Developing powerful athletes part 2: practical applications. Strength Cond J. 2020;Epub ahead of print:1-9.

110. McBride JM, Triplett-McBride NT, Davie A, Newton RU. A comparison of strength and power characteristics between power lifters, olympic lifters, and sprinters. J Strength Cond Res. 1999;13(1):58-66.

111. Hakkinen K, Alen M, Komi PV. Neuromuscular, ananerobic and aerobic performance characteristics of elite power athletes. Eur J Appl Physiol. 1984; 53:97-105.

112. Cormie P, McGuigan MR, Newton RU. Adaptations in athletic performance after ballistic power versus strength training. Med Sci Sports Exerc. 2010; 42(8):1582-98.

113. Aagaard P, Simonsen EB, Andersen $J$, Magnusson P, Dyhre-Poulsen P. Increased rate of force development and neural drive of human skeletal muscle following resistance training. J Appl Physiol (1985). 2002;93: 1318-26.

114. Stone MH, Sands WA, Carlock J, Callan S, Dickie D, Daigle K, et al. The importance of isometric maximum strength and peak rate-of-force development in sprint cycling. J Strength Cond Res. 2004;18(4):878-84

115. Vercoe J, McGuigan MR. Relationship between strength and power production capacities in trained sprint track cyclists. Kinesiol. 2018;50(Suppl. 1):96-101.

116. Folland JP, Williams AG. The adaptations to strength training: morphological and neurological contributions to increased strength. Sports Med. 2007; 37(2):145-68.

117. Kordi M, Folland J, Goodall S, Haralabidis N, Maden-Wilkinson T, Patel TS, et al. Mechanical and morphological determinants of peak power output in elite cyclists. Scand J Med Sci Sports. 2020;30(2):227-37.

118. Hakkinen K, Komi PV, Alen M, Kauhanen H. EMG, muscle fibre and force production characteristics during a 1 year training period in elite weightlifters. Eur J Appl Physiol. 1987;56:419-27.

119. Wilson GJ, Newton RU, Murphy AJ, Humphries BJ. The optimal training load for the development of dynamic athletic performance. Med Sci Sports Exerc. 1993;25(11):1279-86.

120. Sleivert G, Backus RD, Wenger HA. The influence of a strength-sprint training sequence on multi-joint power output. Med Sci Sports Exerc. 1995; 27(12):1655-65.

121. Cormie P, McGuigan MR, Newton RU. Influence of strength on magnitude and mechanisms of adaptation to power training. Med Sci Sports Exerc. 2010;42(8):1566-81.

122. Stone MH, O'Bryan H, Garhammer J, McMillan J, Rozenek R. A theoretical model of strength training. Nat Strength Coach Ass J. 1982;4(4):36-9.

123. Guerriero A, Varalda C, Piacentini MF. The role of velocity based training in the strength periodization for modern athletes. J Funct Morph Kines. 2018; 3(55):1-13.

124. Pareja-Blanco F, Rodriguez-Rosell D, Sanchez-Medina L, Sanchis-Moysi J, Dorado C, Mora-Custodio R, et al. Effects of velocity loss during resistance training on athletic performance, strength gains and muscle adaptations. Scand J Med Sci Sports. 2016;27(7):724-35.

125. Douglas J, Pearson S, Ross A, McGuigan M. Chronic adaptations to eccentric training: a systematic review. Sports Med. 2017;47:917-41.

126. Douglas J, Pearson S, Ross A, McGuigan M. Effects of accentuated eccentric loading on muscle properties, strength, power and speed in resistancetrained rugby players. J Strength Cond Res. 2018;32(10):2750-61.

127. Aagaard P. Training-induced changes in neural function. Exerc Sport Sci Rev. 2003;31(2):61-7.
128. Harden M, Wolf A, Evans M, Hicks KM, Thomas K, Howatson G. Four weeks of augmented eccentric loading using a novel leg press device improved leg strength in well-trained athletes and professional sprint track cyclists. PLOS One. 2020;15(7):1-13.

129. Delitto A, Brown M, Strube MJ, Rose SJ, Lehman RC. Electrical stimulation of quadriceps femoris in an elite weight lifter: a single subject experiment. Int J Sports Med. 1989;10(3):187-91.

130. Filipovic A, Kleinhoder H, Dormann U, Mester J. Electromyostimulation - a systematic review of the effects of different electromyostimulation methods on selected strength parameters in trained and elite athletes. J Strength Cond Res. 2012;26(9):2600-14.

131. Behm DG, Sale DB. Velocity specificity of resistance training. Sports Med. 1993;15(6):374-88.

132. Hakkinen $\mathrm{K}$, Komi PV, Alen M. Effect of explosive type strength training on isometric force- and relaxation-time, electromyographic and muscle fiber characteristics of leg extensor muscles. Acta Physiol Scand. 1985;125:587-600.

133. Kyrolainen H, Avela J, McBride JM, Koskinen S, Andersen JL, Sipila S, et al. Effects of power training on muscle structure and neuromuscular performance. Scand J Med Sci Sports. 2005;15:58-64.

134. Tillin NA, Folland JP. Maximal and explosive strength training elicit distinct neuromuscular adaptations, specific to the training stimulus. Eur J Appl Physiol. 2014;114:365-74.

135. Tanghe KK, Martin JC. Heavy and explosive training differentially affect modeled cyclic muscle power. Med Sci Sports Exerc. 2020;52(5):1068-75.

136. Hakkinen $\mathrm{K}$, Alen M, Komi PV. Changes in isometric force- and relaxationtime, electromyographic and muscle fibre characteristics of human skeletal muscle during strength training and detraining. Acta Physiol Scand. 1985; 125:573-85.

137. Widrick JJ, Stelzer JE, Shoepe TC, Garner DP. Functional properties of human muscle fibers after short-term resistance exercise training. Am J Physiol. 2002;283:R408-R16.

138. Aagaard P, Andersen JL, Bennekou M, Larsson B, Olesen JL, Crameri R, et al. Effects of resistance training on endurance capacity and muscle fiber composition in young top-level cyclists. Scand J Med Sci Sports. 2011;21: e298-307.

139. Adams GR, Hather BM, Baldwin KM, Dudley GA. Skeletal muscle myosin heavy chain composition and resistance training. J Appl Physiol. 1993;74(2): 911-5.

140. Hather BM, Tesch PA, Buchanan P, Dudley GA. Influence of eccentric actions on skeletal muscle adaptations to resistance training. Acta Physiol Scand. 1991;143:177-85.

141. Andersen JL, Aagaard P. Myosin heavy chain IIx overshoot in human skeletal muscle. Muscle Nerve. 2000;23:1095-104.

142. Staron RS, Malicky ES, Leonardi MJ, Falkel JE, Hagerman FC, Dudley GA. Muscle hypertrophy and fast fiber type conversions in heavy resistancetrained women. Eur J Appl Physiol. 1989;60:71-9.

143. Lievens E, Klass M, Bex T, Derave W. Muscle fibre typology substantially influences time to recover from high-intensity exercise. J Appl Physiol. 2020; 128(3):648-59.

144. Gollnick PD, Armstrong RB, Saltin B, Saubert CW IV, Sembrowich WL, Shepherd RE. Effect of training on enzyme activity and fiber composition in human skeletal muscle. J Appl Physiol. 1973;34(1):107-11.

145. Andersen $\mathrm{J}$, Aagaard P. Effects of strength training on muscle fiber types and size; consequences for athletes training for high-intensity sport. Scand J Med Sci Sports. 2010;20(Suppl 2):32-8.

146. Ross A, Leveritt M. Long-term metabolic and skeletal muscle adaptations to short-sprint training: implications for sprint training and tapering. Sports Med. 2001;31(15):1063-82.

147. Jansson E, Esbjornsson M, Holm I, Jacobs I. Increase in the proportion of fast-twitch muscle fibres by sprint training in males. Acta Physiol Scand. 1990;140:359-63.

148. Esbjornsson M, Hellsten-Westing Y, Balsom PD, Sjodin B, Jansson E. Muscle fibre type changes with sprint training: effect of training pattern. Acta Physiol Scand. 1993;149:245-6.

149. Andersen LL, Andersen JL, Magnusson SP, Suetta C, Madsen JL, Christensen $L R$, et al. Changes in the human muscle force-velocity relationship in response to resistance training and subsequent detraining. J Appl Physiol. 2005:99:87-94.

150. Mujika I, Padilla S. Detraining: loss of training-induced physiological and performance adaptations. part l: short term insufficient training stimulus. Sports Med. 2000;30(2):79-87. 
151. Hortobagyi T, Houmard JA, Stevenson JR, Fraser DD, Johns RA, Israel RG. The effects of detraining on power athletes. Med Sci Sports Exerc. 1993: 25(8):929-35.

152. Paddon-Jones D, Leveritt M, Lonergan A, Abernethy P. Adaptation to chronic eccentric exercise in humans: the influence of contraction velocity. Eur J Appl Physiol. 2001;85:466-71.

153. Leong CH, McDermott WJ, Elmer SJ, Martin JC. Chronic eccentric cycling improves quadriceps muscle structure and maximum cycling power. Int J Sports Med. 2014;35:559-65.

154. Hakkinen K, Komi PV, Tesch PA. Effect of combined concentric and eccentric strength training and detraining on force-time, muscle fiber and metabolic characteristics of leg extensor muscles. Scand J Med Sci Sports. 1981;3(2):50-8.

155. Froese EA, Houston ME. Performance during the wingate anaerobic test and muscle morphology in males and females. Int J Sports Med. 1987;8:35-9.

156. Schaffer PJ, Lindstedt SL. How animals move: comparative lessons on animal locomotion. Compr Physiol. 2013;3(1):289-314.

157. Martin DT. Generating anaerobic power. In: Joyce D, Lewindon D, editors. High-performance training for sports. Human Kinetics; 2014. p. 199-210.

158. Martin JC, Diedrich D, Coyle EF. Time course of learning to produce maximum cycling power. Int J Sports Med. 2000;21:485-7.

159. Dorel S, Bourdin M, Van Praagh E, Lacour JR, Hautier CA. Influence of two pedalling rate conditions on mechanical output and physiological responses during all-out intermittent exercise. Eur J Appl Physiol. 2003;89: 157-65.

160. Bundle MW, Ernst CL, Bellizzi MJ, Wright S, Weyand PG. A metabolic basis for impaired muscle force production and neuromuscular compensation during sprint cycling. Am J Physiol Regul Integr Comp Physiol. 2006;291: R1457-R64.

161. Weyand PG, Lin JE, Bundle MW. Sprint performance-duration relationships are set by the fractional duration of external force production. Am J Physiol Regul Integr Comp Physiol. 2006;290:R758-R65.

162. Burnley M, Jones AM. Power-duration relationship: physiology, fatigue and the limits of human performance. Eur J Sport Sci. 2018;18(1):1-12.

163. Beelen A, Sargeant AJ. Effect of fatigue on maximal power output at different contraction velocities in humans. J Appl Physiol. 1991;71(6):2332-7.

164. Gardner AS, Martin DT, Jenkins DG, Dyer I, Van Eiden J, Barras M, et al. Velocity-specific fatigue: quantifying fatigue during variable velocity cycling. Med Sci Sports Exerc. 2009;41(4):904-11.

165. O'Bryan SJ, Brown NA, Billaut F, Rouffet DM. Changes in muscle coordination and power output during sprint cycling. Neurosci Lett. 2014; 25(576):11-6.

166. Chtourou H, Zarrouk N, Chaouachi A, Dogui M, Behm DG, Chamari K, et al. Diurnal variation in wingate-test performance and associated electromyographic parameters. Chronobiol Int. 2011;28(8):706-13.

167. Jones NL, McCartney N, Graham T, Spriet LL, Kowalchuk JM, Heigenhauser GJ, et al. Muscle performance and metabolism in maximal isokinetic cycling at slow and fast speeds. J Appl Physiol. 1985;59(1):132-6.

168. Maclntosh BR, Svedahl K, Kim M. Fatigue and optimal conditions for shortterm work capacity. Eur J Appl Physiol. 2004;92:369-75.

169. Bar-Or O. The wingate anaerobic test: an update on methodology, reliability and validity. Sports Med. 1987;4:381-94.

170. Beneke R, Pollman C, Bleif I, Leithauser RM, Hutler M. How anaerobic is the wingate anaerobic test for humans? Eur J Appl Physiol. 2002;87:388-92.

171. Gastin PB. Energy system interaction and relative contribution during maximal exercise. Sports Med. 2001;31(10):725-41.

172. Beelen A, Sargeant AJ, Jones DA, de Ruiter CJ. Fatigue and recovery of voluntary and electrically elicited dynamic force in humans. J Physiol. 1995; 484(1):227-35

173. Ferguson RA, Ball D, Krustrup P, Aagaard P, Kjaer M, Sargeant AJ, et al. Muscle oxygen uptake and energy turnover during dynamic exercise at different contraction frequencies in humans. J Physiol. 2001;536(1):261-71.

174. Buttelli O, Seck D, Vandewalle H, Jouanin JC, Monod H. Effect of fatigue on maximal velocity and maximal torque during short exhausting cycling. Eur J Appl Physiol. 1996;73:175-9.

175. De Ruiter CJ, Jones DA, Sargeant AJ, De Haan A. The measurement of force/ velocity relationships of fresh and fatigued human adductor pollicis muscle. Eur J Appl Physiol. 1999;80:386-93.

176. De Ruiter CJ, Didden WJM, Jones DA, De Haan A. The force-velocity relationship of human adductor pollicis muscle during stretch and the effects of fatigue. J Physiol. 2000;526(3):671-81.
177. Crow MT, Kushmerick MJ. Correlated reduction of velocity of shortening and the rate of energy utilization in mouse fast-twitch muscle during a continuous tetanus. J Gen Physiol. 1983;82:703-20.

178. Jones DA, de Ruiter CJ, de Haan A. Change in contractile properties of human muscle in relationship to the loss of power and slowing of relaxation seen with fatigue. J Physiol. 2006;576(3):913-22.

179. Bigland-Ritchie B, Johansson R, Lippold OCJ, Woods JJ. Contractile speed and EMG changes during fatigue of sustained maximal voluntary contractions. J Neurophysiol. 1983;50(1):313-24.

180. Jones DA. Changes in the force-velocity relationship of fatigued muscle: implications for power production and possible causes. J Physiol. 2010; 588(16):2977-86.

181. Byrd SK, McCutcheon LJ, Hodgson DR, Gollnick PD. Altered sarcoplasmic reticulum function after high-intensity exercise. J Appl Physiol. 1989;67(5): 2072-7.

182. Thorstensson A, Karlsson J. Fatiguability and fibre composition of human skeletal muscle. Acta Physiol Scand. 1976;98:318-22.

183. Billaut F, Basset FA, Falgairette G. Muscle coordination changes during intermittent cycling sprints. Neurosci Lett. 2005;380:265-9.

184. Ament W, Verkerke GJ. Exercise and fatigue. Sports Med. 2009;39(5):389-422.

185. Amann M. Central and peripheral fatigue: interaction during cycling exercise in humans. Med Sci Sports Exerc. 2011;43(11):2039-45.

186. Maclntosh BR, Holash RJ, Renaud J-M. Skeletal muscle fatigue - regulation of excitation-contraction coupling to avoid metabolic catastrophe. J Cell Sci. 2012;125:2105-14

187. Karatzaferi C, De Haan A, Ferguson RA, van Mechelen W, Sargeant AJ. Phosphocreatine and ATP content in human single muscle fibres before and after maximum dynamic exercise. Pflugers Arch - Eur J Physiol. 2001; 442:467-74.

188. Karatzaferi C, De Haan A, van Mechelen W, Sargeant AJ. Metabolic changes in single human muscle fibres during brief maximal exercise. Exp Physiol. 2001;86(3):411-5

189. Allen DG, Lamb GD, Westerblad H. Skeletal muscle fatigue: cellular mechanisms. Physiol Rev. 2008;88:287-332.

190. Fitts RH. The cross-bridge cycle and skeletal muscle fatigue. J Appl Physiol. 2008;104:551-8.

191. Westerblad H, Allen DG, Lannergren J. Muscle fatigue: lactic acid or inorganic phosphate the major cause? News Physiol Sci. 2002;17:17-21.

192. Dahlstedt AJ, Katz A, Westerblad H. Role of myoplasmic phosphate in contractile function of skeletal muscle: studies on creatine kinase-deficient mice. J Physiol. 2001;533(2):379-88.

193. Messonier L, Kristensen M, Juel C, Denis C. Importance of $\mathrm{pH}$ regulation and lactate/H+ transport capacity for work production during supramaximal exercise in humans. J Appl Physiol. 2007;102:1936-44.

194. Linari M, Caremani M, Lombardi V. A kinetic model that explains the effects of inorganic phosphate on the mechanics and energetics of isometric contraction of fast skeletal muscle. Proc R Soc B. 2010:277:19-27.

195. Metzger JM, Moss RL. Effects of tension and stiffness due to reduced $\mathrm{pH}$ in mammalian fast- and slow-twitch skinned skeletal muscle fibres. J Physiol. 1990:428:737-50.

196. Stephenson DG, Lamb GD, Stephenson GMM. Events of the excitationcontraction-relaxation (E-C-R) cycle in fast- and slow-twitch mammalian muscle fibres relevant to muscle fatigue. Acta Physiol Scand. 1998;162:229-45.

197. Kordi M, Menzies C, Parker SL. Relationship between power-duration parameters and mechanical and anthropometric properties of the thigh in elite cyclists. Eur J Appl Physiol. 2018;118(3):637-45.

198. Vanhatalo A, Fulford J, DiMenna FJ, Jones AM. Influence of hyperoxia on muscle metabolic responses and the power-duration relationship during severe-intensity exercise in humans: a 31P magnetic resonance spectroscopy study. Exp Physiol. 2010;95(4):528-40.

199. Skiba PF, Fulford J, Clarke DC, Vanhatalo A, Jones AM. Intramuscular determinants of the ability to recover work capacity above critical power. Eur J Appl Physiol. 2015;115(4):703-13.

200. Vanhatalo A, Black MI. J. DF, Blackwell JR, Schmidt JF, Thompson C et al. The mechanistic bases of the power-time relationship: muscle metabolic responses and relationships to muscle fibre type. J Physiol. 2016:594(15): 4407-23.

201. Glaister M. Multiple sprint work: physiological responses, mechanisms of fatigue and the influence of aerobic fitness. Sports Med. 2005;35(9):757-77.

202. Clark JF. Creatine and phosphocreatine: a review of their use in exercise and sport. J Athl Train. 1997;32(1):45-51. 
203. Baguet A, Koppo K, Pottier A, Derave W. B-alanine supplementation reduces acidosis but not oxygen uptake response during high-intensity cycling exercise. Eur J Appl Physiol. 2010;108:495-503.

204. Sjogaard G. Capillary supply and cross-sectional area of slow and fast twitch muscle fibres in man. Histochem. 1982;76:547-55.

205. Bar-Or O, Dotan R, Inbar O, Rothstein A, Karlsson J, Tesch P. Anaerobic capacity and muscle fiber type distribution in man. Int J Sports Med. 1980;1: 82-5.

206. Inbar O, Kaiser P, Tesch P. Relationships between leg muscle fiber type distribution and leg exercise performance. Int J Sports Med. 1981;2:154-9.

207. Creer AR, Ricard MD, Conlee RK, Hoyt GL, Parcell AC. Neural, metabolic and performance adaptations to four weeks of high intensity sprint-interval training in trained cyclists. Int J Sports Med. 2004;25:92-8.

208. Stathis CG, Febbraio MA, Carey MF, Snow RJ. Influence of sprint training on human skeletal muscle purine nucleotide metabolism. J Appl Physiol. 1994; 76(4):1802-9.

209. Jacobs I, Esbjornsson M, Sylven C, Holm I, Jansson E. Sprint training effects on muscle myoglobin, enzymes, fiber types, and blood lactate. Med Sci Sports Exerc. 1987;19(4):368-74

210. MacDougall JD, Hicks AL, MacDonald JR, McKelvie RS, Green HJ, Smith KM. Muscle performance and enzymatic adaptations to sprint interval training. J Appl Physiol. 1998;84(6):2138-42.

211. Sharp RL, Costill DL, Fink WJ, King DS. Effects of eight weeks of bicycle ergometer sprint training on human muscle buffer capacity. Int J Sports Med. 1986;7:13-7.

212. McKenna MJ, Heigenhauser GJ, McKelvie RS, MacDougall JD, Jones NL. Sprint training enhances ionic regulation during intense exercise in men. J Physiol. 1997;501(3):687-702.

213. laia FM, Bangsbo J. Speed endurance training is a powerful stimulus for physiological adaptations and performance improvements of athletes. Scand J Med Sci Sports. 2010;20(Suppl. 2):11-23.

214. Gibala MJ, Hawley JA. Sprinting toward fitness. Cell Metab. 2017;25(2):988-90.

215. Juel C. Regulation of $\mathrm{pH}$ in human skeletal muscle: adaptations to physical activity. Acta Physiol. 2008;193:17-24.

216. Pilegaard H, Domino K, Noland T, Juel C, Hellsten Y, Halestrap AP, et al. Effect of high-intensity exercise training on lactate/H+ transport capacity in human skeletal muscle. Am J Physiol. 1999;276(2):E255-E61.

217. Pilegaard $H$, Terzis $G$, Halestrap A, Juel C. Distribution of the lactate/H+ transporter isoforms MCT1 and MCT4 in human skeletal muscle. Am J Physiol. 1999;276:E843-E8.

218. Juel C. Training-induced changes in membrane transport proteins of human skeletal muscle. Eur J Appl Physiol. 2006;96:627-35.

219. Klich S, Krymski I, Kawczynski A. Viscoelastic properties of lower extremity muscles after elite track cycling sprint events: a case report. Centr Eur J Sport Sci Med. 2020;29(1):5-10.

220. Joyner MJ, Coyle EF. Endurance exercise performance: the physiology of champions. J Physiol. 2008;586(1):35-44.

221. Laursen PB. Training for intense exercise performance: high-intensity or high-volume training? Scand J Med Sci Sports. 2010;20(Suppl. 2):1-10.

222. Gibala MJ, Little JP, van Essen M, Wilkin GP, Burgomaster KA, Safdar A, et al. Short-term sprint interval versus traditional endurance training: similar initial adaptations in human skeletal muscle and exercise performance. J Physiol. 2006:575(3):901-11.

223. Fyfe JJ, Bartlett JD, Hanson ED, Stepto NK, Bishop DJ. Endurance training intensity does not mediate interference to maximal lower-body strength gain during short-term concurrent training. Front Physiol. 2016;7(487):1-16.

224. Hawley JA. Molecular responses to strength and endurance training: are they incompatible? Appl Physiol Nutr Metab. 2009;34:355-61.

225. Fyfe JJ, Bishop DJ, Stepto NK. Interference between concurrent resistance and endurance exercise: molecular bases and the role of individual training variables. Sports Med. 2014:44:743-62.

226. Brocherie F, Girard O, Faiss R, Millet GP. Effects of repeated sprint training in hypoxia on sea-level performance: a meta-analysis. Sports Med. 2017;47(8): 1651-60.

227. van der Zwaard S, Brocherie F, Kom BLG, Millet GP, Deldicque L, van der Laarse WJ, et al. Adaptations in muscle oxidative capacity, fiber size, and oxygen supply capacity after repeated sprint training in hypoxia combined with chronic hypoxic exposure. J Appl Physiol. 2018;124:1403-12.

228. Faiss R, Leger B, Vesin J-M, Fournier P-E, Eggel Y, Deriaz O, et al. Significant molecular and systemic adaptations after repeated sprint training in hypoxia. PLOS One. 2013;8(2):1-13.
229. Gore CJ, Clark SA, Saunders PU. Nonhematoloical mechanisms of improved sea-level performance after hypoxic exposure. Med Sci Sports Exerc. 2007; 39(9):1600-9.

230. Hoppeler H, Vogt M. Muscle tissue adaptations to hypoxia. J Exp Biol. 2001; 204:3133-9.

231. Abbiss CR, Karagounis LG, Laursen PB, Peiffer JJ, Martin DT, Hawley JA, et al. Single-leg cycle training is superior to double-leg cycling in improving the oxidative potential and metabolic profile of trained skeletal muscle. J Appl Physiol. 2011;110:1248-55.

\section{Publisher's Note}

Springer Nature remains neutral with regard to jurisdictional claims in published maps and institutional affiliations.

\section{Submit your manuscript to a SpringerOpen ${ }^{\circ}$ journal and benefit from:}

- Convenient online submission

- Rigorous peer review

- Open access: articles freely available online

High visibility within the field

- Retaining the copyright to your article

Submit your next manuscript at $\boldsymbol{\nabla}$ springeropen.com 